\title{
PERGESERAN PARADIGMA HUKUM INVESTASI PERTAMBANGAN
}

(Mining Investment Law Paradigm Shifts)

\author{
Henry Donald Lbn. Toruan \\ Pusat Penelitian dan Pengembangan Sistem Hukum Nasional \\ Badan Pembinaan Hukum Nasional \\ J. Mayjen Soetoyo No. 10 Cililitan, Jakarta \\ Email: henrydonald.It@gmail.com
}

Naskah diterima: 30 Juni 2015; revisi: 18 Agustus 2015; disetujui: 19 Agustus 2015

\begin{abstract}
Abstrak
Peratuan mengenai pertambangan di Indonesia, dikenal suatu bentuk kerjasama yang juga sudah diterima di kalangan pertambangan internasional yaitu dengan model kontrak karya, dimana Pemerintah Indonesia sebagai Principal, sedangkan perusahaan menjadi kontraktor. Namun seriring waktu terlihat bagaimana luasnya kewenangan perusahaan pertambangan. Sehingga Model kerjasama atas dasar kontrak karya dalam investasi pertambangan, dipandang sebagai biang keladi ketidak berdaulatan Negara atas tambang. Karena pemerintah diposisikan sebagai badan hukum privat, yang mempunyai kedudukan yang sejajar dengan badan hukum privat perusahaan pertambangan. Oleh karena itu pemerintah Indonesia melakukan perubahan regulasi di bidang penanaman modal dan pertambangan. Kemudian, apa yang harus dilakukan pemerintah dalam menyikapi penyesuaian kontrak karya menjadi Izin Usaha Pertambangan Khusus (IUPK). Lalu, apakah pergeseran pradigma hukum investasi pertambangan tersebut akan memberikan kemanfaatan dan kepastian hukum? Untuk menjawab pertanyaan ini dilakukan dengan menggunakan pendekatan normatif. Didapatkan jawaban bahwa pergeseran pradigma hukum investasi pertambangan di Indonesia dari Kontrak Karya menjadi IUPK, menjadikan Negara berkuasa atas mineral dan tambang. Pergeseran pradigma ini diharapkan akan dapat memberikan nilai tambah (value added) yang diciptakan oleh sektor-sektor produktif seperti pertambangan bagi peningkatan pendapatan pada perekonomian nasional. Sehingga akan memberikan kemanfaatan yang sebesar-besarnya pada masyarakat, yaitu kesejahteraan baik itu pendidikan, lapangan pekerjaân dan sebagainya.

Kata kunci: hukum investasi pertambangan, kontrak karya, kesejahteraan rakyat
\end{abstract}

\begin{abstract}
Mining regulation in Indonesia recognize a work contract model which is also known in international level as a common model of agreement, where Government of Indonesia as principal while foreign company as contractor. As time passed, it can be seen that mining company had huge authority over a mining. Work Contract often been pointed as a caused of the dissoverignty of a county over mining. It is because government has been positioned as private legal entity as in the same level as private mining company. Thus government of Indonesia makes changes in investment and mining regulation. In order to adjust with this changing (of Work Contract to Special Minning Permit) what the Government must do? And how is the paradigm shift of investment law in mining in Indonesia gives benefit and legal certainty? To get answers to these questions, this research is conducted with normative approach. The research's findings are that paradigm shifts in Indonesia's Mining investment law make Government of Indonesia has absolute power over mining. Hence this shift can give value added created by the productive sectors for the increasing revenue of national economic. And in the end, it will give huge benefits to Indonesian people, that is welfare in education, jobs, etc.
\end{abstract}

Keywords: mining investment law, contract of work, people's welfare 


\section{A. Pendahuluan}

Salah satu tujuan pembentukan Pemerintahan Negara Indonesia adalah untuk memajukan kesejahteraan umum, demikian diamanatkan dalam mukadimah UUD 1945. Oleh karena itu, dirumuskanlah dalam Pasal 33 ayat (3) UUD 1945 bahwa "Bumi dan air dan kekayaan alam yang terkandung di dalamnya dikuasai oleh negara dan dipergunakan untuk sebesar-besar kemakmuran rakyat." Kekayaan alam yang dimaksud adalah sumber daya alam (SDA) yang masih terpendam, terbentang dari Sabang sampai Merauke. Namun belum termanfaatkan secara optimal karena ketiadaan modal, teknologi dan tenaga terampil untuk mengolah SDA tersebut menjadi kekuatan ekonomi riil.

Masa awal pemerintahan orde baru diterbitkanlah Undang-Undang Nomor 1 Tahun 1967 tentang Penanaman Modal Asing (UU PMA), sebagai upaya mengundang modal asing berinvestasi di Indonesia. Dengan tujuan untuk mempercepat pembangunan ekonomi terutama sektor-sektor yang belum dapat dilaksanakan sendiri. Tidak berapa lama kemudian, pemerintah menerbitkan UndangUndang Nomor 11 Tahun 1967 tentang PokokPokok Pertambangan. Ketentuan ini memberi kewenangan pada Menteri Pertambangan untuk menunjuk perusahaan asing sebagai kontraktor, untuk melaksanakan pekerjaan-pekerjaan yang belum dapat dilaksanakan sendiri oleh instansi pemerintah atau perusahaan negara. Menteri tersebut bertindak juga selaku pemegang kuasa pertambangan dalam mengadakan perjanjian karya dengan kontraktor asing.
Tiga bulan setelah terbitnya UU PMA, pada April 1967 Freeport adalah pemodal asing pertama yang masuk ke Indonesia. Setelah itu, pada kurun 1968 masuk 16 pertambangan luar negeri, seperti Inco, Bliton Mij, Alcoa, Kennecott, dan US Steel. Pada saat itu, model kontrak karya merupakan produk hukum pertambangan yang sudah diterima kalangan pertambangan internasional. ${ }^{1}$ Namun, setelah empat dasawarsa berlalu, kesejahteraan masyarakat yang dicita-citakan dari sumber daya alam sebagaimana diamanatkan dalam Pasal 33 ayat (3) UUD 1945 tak pernah kunjung tiba. Sementara hasil kegiatan pertambangan yang digerus dari bumi Indonesia, semakin hari makin berkurang bahkan kian menipis. Ironisnya, yang menikmati keuntungan hasil tambang bukan rakyat Indonesia namun perusahaan tambang modal asing. Sehingga masyarakat di daerah yang memiliki sumber daya alam tersebut mulai mempertanyakan manfaat pertambangan bagi mereka.

Kontrak karya merupakan perjanjian antara dua pihak, dimana pemerintah Indonesia sebagai Principal, sedangkan perusahaan menjadi kontraktor. Dalam kontrak karya di sektor mineral, perusahaan merupakan kontraktor tunggal berkaitan dengan wilayah kontrak karya. Dalam hal ini perusahaan diberikan hak tunggal untuk melakukan kegiatan eksplorasi, penambangan, pengolahan penyimpanan dan pengangkutan mineral yang dihasilkan, serta untuk memasarkan dan menjual atau melepaskan semua produksi dari tambang dan mengolah, baik di dalam maupun di luar negeri (Pasal 2 ayat (1) Kontrak Karya Generasi VII). Disamping itu, pemerintah juga memberikan 
hak kendali dan manajemen tunggal kepada perusahaan atas semua kegiatannya, serta memikul semua resiko yang timbul dalam operasinya (Pasal 2 ayat (3) Kontrak Karya generasi VII). ${ }^{2}$

Dari kontrak karya tersebut di atas, terlihat bagaimana luasnya kewenangan perusahaan pertambangan. Sehingga Model kerjasama atas dasar kontrak karya dalam investasi pertambangan, dipandang sebagai biang keladi ketidakberdaulatan Negara atas tambang. Karena pemerintah diposisikan sebagai badan hukum privat, yang mempunyai kedudukan yang sejajar dengan badan hukum privat perusahaan pertambangan. Dengan model kerjasama demikian, perusahaan pertambangan seperti Freeport, memiliki keleluasaan mengeruk sumber daya alam di wilayah pertambangan yang dikuasainya. Lalu, tambang yang dikeruk dikirimkan ke negara asal pemodal untuk dimurnikan. Setelah dimurnikan kita tidak mengetahui hasilnya, apakah berupa mineral logam seperti litium, berilium, magnesium, kalium, kalsium, emas, tembaga, perak, timbal, seng, timah, nikel, mangaan, platina, titanium dan lain-lain, atau berupa mineral radioaktif seperti radium, thorium, uranium, monasit dll. Tentu negara Indonesia sangat dirugikan karena tidak mengetahui hasil akhir dari galian tambang tersebut.

Oleh karena itulah, pemerintah berinisiatif mengubah UU PMA dengan Undang-Undang Nomor 25 Tahun 2007 tentang Penanaman Modal (UU Penanaman Modal). Lalu, mengubah Undang-Undang Nomor 11 tahun 1967 dengan Undang-Undang Nomor 4 Tahun 2009 tentang Pertambangan Mineral dan Batubara (UU
Minerba). Kedua undang-undang ini, tidak lagi mengadopsi model kontrak karya tetapi diubah menjadi kerjasama dalam bentuk izin usaha pertambangan khusus (IUPK). Pergeseran paradigma hukum investasi pertambangan ini, bertujuan meningkatkan pendapatan negara bagi kesejahteraan masyarakat.

Pemberlakuan UU Minerba sejak 12 Januari 2009 lalu, memang menimbulkan keresahan terutama investor pertambangan asing pemegang kontrak karya. Hingga saat ini masih belum terdapat titik temu antara pemerintah sebagai regulator dengan investor asing dibidang pertambangan tersebut. Pemerintah menghendaki agar perusahaan pemegang kontrak karya segera menyesuaikan kontrak karya dengan ketentuan UU Minerba. Persoalannya, kalau mengubah kontrak karya menyesuaikannya dengan UU Minerba, tentu akan melanggar perjanjian kontrak yang telah disepakati pemerintah dengan perusahaan pertambangan tersebut yang akan berakhir tahun 2021. Ternyata PT Freeport akhirya menyetujui penyesuaian Kontrak Karya sesuai perintah Pasal 169 huruf b UU Minerba. Namun mereka juga minta agar diberikan Izin Usaha Pertambagan Khusus (IUPK) terhadap PT Freeport.Tampaknya pemerintah sangat hati-hati untuk memutuskan pemberian IUPK, sehingga belum memberikan jawaban kepastian. Pemerintah masih memerlukan berbagai masukan dari masyarakat terutama akademisi untuk menyampaikan kajian mendalam akan perubahan tersebut.

Berasarkan uraian tersebut di atas timbul pertanyaan, apa yang harus dilakukan pemerintah dalam menyikapi penyesuaian

Nanik Trihastuti, Hukum Kontrak Karya: Pola Kerjasama Pengusahaan Pertambangan Indonesia, (Malang: Setara Pers, kelompok Penerbit Intrans, 2013) hlm. 92. 
kontrak karya menjadi Izin Usaha Pertambangan Khusus (IUPK)? Apakah pergeseran paradigma hukum investasi pertambangan tersebut akan lebih memberikan kemanfaatan dan kepastian hukum?

\section{B. Metode Penelitian}

Pendekatan yang digunakan dalam penulisan artikel ini adalah metode penelitian normatif. ${ }^{3}$ Penelitian hukum dilakukan untuk mencari pemecahan atas isu hukum yang timbul. Oleh karena itu, penelitian hukum merupakan suatu penelitian di dalam kerangka know-how dalam hukum. Hasil yang dicapai adalah untuk memberikan preskripsi mengenai apa yang seyogianya atas isu yang diajukan. ${ }^{4}$ Untuk memecahkan isu hukum diperlukan sumber-sumber penelitian. Sumber-sumber penelitian hukum dapat dibedakan menjadi sumber-sumber penelitian yang berupa bahan-bahan hukum primer dan bahan-bahan hukum sekunder. Bahan-bahan hukum primer terdiri dari perundang-undangan, catatancatatan resmi atau risalah dalam pembuatan perundang-undangan dan putusan-putusan hakim. Sedangkan bahan-bahan sekunder berupa semua publikasi tentang hukum yang bukan merupakan dokumen-dokumen resmi. ${ }^{5}$

Dalam melakukan penelitian hukum, dilakukan langkah-langkah (1) mengindentifikasi fakta hukum dan mengeliminir hal-hal yang tidak relevan untuk menetapkan isu hukum yang hendak dipecahkan; (2) pengumpulan bahan-bahan hukum dan sekiranya dipadang mempunyai relevansi juga bahan-bahan non hukum; (3) melakukan telaah atas isu hukum yang diajukan berdasarkan bahan-bahan yang telah dikumpulkan; (4) menarik kesimpulan dan bentuk argumentasi yang menjawab isu hukum; dan (5) memberikan preskripsi berdasarkan argumentasi yang telah dibangun di dalam kesimpulan. ${ }^{6}$

\section{Pembahasan}

\section{Problema implementasi UU Minerba terhadap investasi pertambangan.}

Dalam masyarakat sering dijumpai penggunaan istilah investasi untuk menyebutkan pasar modal dan penanaman modal. Investasi berasal dari kata invest yang berarti menanam atau menginvestasi uang atau modal. Istilah investasi atau penanaman modal merupakan istilah yang dikenal dalam kegiatan bisnis sehari-hari maupun dalam bahasa perundangundangan. Istilah investasi merupakan istilah yang populer dalam dunia usaha, sedangkan istilah penanaman modal lazim digunakan dalam perundang-undangan. Namun pada dasarnya kedua istilah tersebut mempunyai pengertian yang sama, sehingga kadangkala digunakan secara interchangeable. ${ }^{7}$ Demikian juga dalam tulisan ini akan menggunakan kedua istilah itu secara bergantian dengan pengertian yang sama.

Pengertian Penanaman modal dalam Pasal 1 UU Penanaman Modal, adalah: 
"segala bentuk kegiatan menanam modal, baik oleh penanam modal dalam negeri maupun penanam modal asing untuk melakukan usaha di wilayah negara Republik Indonesia (ayat (1)). Sedangkan Penanaman modal asing adalah kegiatan menanam modal untuk melakukan usaha di wilayah negara Republik Indonesia yang dilakukan oleh penanam modal asing, baik yang menggunakan modal asing sepenuhnya maupun yang berpatungan dengan penanam modal dalam negeri (ayat (3))".

Sedangkan istilah hukum pertambangan merupakan terjemahan dari bahasa Inggris, yaitu mining law. Menurut H. Salim HS hukum pertambangan adalah:

"keseluruhan kaidah hukum yang mengatur kewenangan negara dalam pengelolaan bahan galian (tambang) dan mengatur hubungan hukum antara negara dan orang dan atau badan hukum dalam pengelolaan dan pemanfaatan bahan galian (tambang)."

Sementara pengertian pertambangan menurut UU Minerba dalam Pasal 1 ayat (1) disebutkan bahwa:

"Pertambangan adalah sebagian atau seluruh tahapan kegiatan dalam rangka penelitian, pengelolaan dan pengusahaan mineral atau batubara yang meliputi penyelidikan umum, eksplorasi, studi kelayakan, konstruksi, penambangan, pengolahan dan pemurnian, pengangkutan dan penjualan, serta kegiatan pasca tambang".

Menurut ketentuan Pasal 5 UU Penanaman Modal, bahwa:

(2) Penanaman modal asing wajib dalam bentuk perseroan terbatas berdasarkan hukum Indonesia dan berkedudukan di dalam wilayah negara Republik Indonesia, kecuali ditentukan lain oleh undang-undang.
(3) Penanam modal dalam negeri dan asing yang melakukan penanaman modal dalam bentuk perseroan terbatas dilakukan dengan:

a. mengambil bagian saham pada saat pendirian perseroan terbatas;

b. membeli saham; dan

c. melakukan cara lain sesuai dengan ketentuan peraturan perundangundangan

Dalam Undang-Undang Nomor 40 Tahun 2007 tentang Perseroan Terbatas (UUPT) Pasal 1 ayat (1) disebutkan bahwa:

"Perseroan Terbatas, yang selanjutnya disebut perseroan, adalah badan hukum yang merupakan persekutuan modal, didirikan berdasarkan perjanjian, melakukan kegiatan usaha dengan modal dasar yang seluruhnya terbagi dalam saham dan memenuhi persyaratan yang ditetapkan dalam undangundang ini serta peraturan pelaksanaannya".

Jadi, pendirian perseroan terbatas harus memiliki beberapa orang pemodal minimal 2 (dua) orang, sehingga mereka dapat bersekutu menggabungkan modal untuk membentuk badan hukum perseroan. Begitu juga dengan pendirian perseroan, harus didasarkan pada perjanjian berarti minimal harus ada 2 (dua) orang yang menjadi para pihak.

Mengenai pendirian perseroan terbatas dalam Pasal 7 UUPT disebutkan bahwa:

(1) Perseroan didirikan oleh 2 (dua) orang atau lebih dengan akta notaris yang dibuat dalam bahasa Indonesia.

(2) Setiap pendiri Perseroan wajib mengambil bagian saham pada saat Perseroan didirikan.

Penjelasan Pasal 7 ayat (1) menyebutkan bahwa yang dimaksud dengan "orang" adalah orang perseorangan, baik warga negara

8 H. Salim HS, Hukum Pertambangan di Indonesia, (Jakarta: Rajawali Pers, Ed.1- Cet. 6, 2012), hlm. 7 
Indonesia maupun asing atau badan hukum Indonesia atau asing. Ketentuan dalam ayat ini menegaskan prinsip yang berlaku berdasarkan undang-undang ini bahwa pada dasarnya sebagai badan hukum, Perseroan didirikan berdasarkan perjanjian, karena itu mempunyai lebih dari 1 (satu) orang pemegang saham.

Selanjutnya dalam Pasal 8 UUPT disebutkan bahwa:

(1) Akta pendirian memuat anggaran dasar dan keterangan lain berkaitan dengan pendirian Perseroan.

(2) Keterangan lain sebagaimana dimaksud pada ayat (1) memuat sekurang-kurangnya:

a. nama lengkap, tempat dan tanggal lahir, pekerjaan, tempat tinggal, dan kewarganegaraan pendiri perseorangan, atau nama, tempat kedudukan dan alamat lengkap serta nomor dan tanggal keputusan menteri mengenai pengesahan badan hukum dari pendiri Perseroan;

b. nama lengkap, tempat dan tanggal lahir, pekerjaan, tempat tinggal, kewarganegaraan anggota Direksi dan Dewan Komisaris yang pertama kali diangkat;

c. nama pemegang saham yang telah mengambil bagian saham, rincian jumlah saham, dan nilai nominal saham yang telah ditempatkan dan disetor.

Penjelasan Pasal 8 ayat (2) Huruf a disebutkan bahwa dalam mendirikan Perseroan diperlukan kejelasan mengenai kewarganegaraan pendiri. Pada dasarnya badan hukum Indonesia yang berbentuk Perseroan didirikan oleh warga negara Indonesia atau badan hukum Indonesia. Namun, kepada warga negara asing atau badan hukum asing diberikan kesempatan untuk mendirikan badan hukum
Indonesia yang berbentuk Perseroan sepanjang undang-undang yang mengatur bidang usaha Perseroan tersebut memungkinkan, atau pendirian Perseroan tersebut diatur dengan undang-undang tersendiri. Dalam hal pendiri adalah badan hukum asing, nomor dan tanggal pengesahan badan hukum pendiri adalah dokumen yang sejenis dengan itu, antara lain certificate of incorporation. Dalam hal pendiri adalah badan hukum negara atau daerah, diperlukan peraturan pemerintah tentang penyertaan dalam Perseroan atau peraturan daerah tentang penyertaan daerah dalam Perseroan.

Jika dicermati bunyi Pasal 7 UUPT dikaitkan dengan Pasal 1 ayat (3) UU Penanaman Modal berarti penanaman modal asing dapat melakukan kegiatan usaha dengan menggunakan modalasing sepenuhnya. Menjadi pertanyaan bagaimana caranya pendirian badan hukum yang dilakukan oleh pemodal asing sepenuhnya atau $100 \%$ modal asing di Indonesia? Sementara pendirian perseroan mensyaratkan harus ada beberapa pemodal dan dibentuk dengan perjanjian berarti minimal harus ada dua pihak. Apakah ini dimaksudkan bahwa investor asing yang akan menanamkan modal di Indonesia sebagai satu pihak dengan badan hukum asing miliknya dipihak lain, membuat perjanjian mendirikan badan hukum perseroan terbatas di Indonesia. Sebab, badan hukum ini juga dipersamakan dengan orang yang dianggap cakap melakukan perbuatan hukum dalam lingkup perjanjian. Hanya saja karena ia bukan manusia yang berwujud, maka untuk bertindak ia diwakilkan oleh Direksi. Jika demikian berarti pemilikan perusahaan, baik yang didirikan di negara asal investor dengan pendirian perusahaan baru di Indonesia, hanya dimiliki oleh satu orang. Agar dapat mengikuti 
persyaratan pendirian perseroan menurut Pasal 7 UUPT, maka badan hukum perseroan miliknya di negara asal investor dijadikan sebagai pihak lain. Bila dikaitkan dengan penjelasan Pasal 8 UUPT yang mengatakan "sepanjang undangundang yang mengatur bidang usaha Perseroan tersebut memungkinkan, atau pendirian Perseroan tersebut diatur dengan undangundang tersendiri". Sementara undang-undang tersendiri belum ada, maka harus merujuk pada bidang usaha dari perseroan, yaitu pertambangan. Dalam UU Minerba memang memperbolehkan modal asing berinvestasi dibidang pertambangan dengan pemberian IUPK.

Investasi dalam sektor pertambangan merupakan kegiatan usaha padat modal, teknologi dan keahlian, hanya dikuasai sekelompok kecil perusahaan modal asing yang diungkapkan dalam berbagai istilah. Di dalam bidang ekonomi istilah yang dipergunakan untuk perusahaan transnasional masih beraneka warna seperti international companies, multinational corporation, multinational enterprise atau transnational enterprises dan lain-lain. ${ }^{9}$ Pilihan kita jatuh pada pengertian multinational enterprise karena istilah ini mencerminkan adanya suatu network of corporate and noncorporate entities in different countries joined together by ties of ownership. Sehingga istilah transnational corporation (disingkat TNC) dapat dipakai dalam arti: salah satu bagian(subsidiary atau affliate) dari transnational enterprise (TNE). ${ }^{10}$
Menurut Sunaryati Hartono bahwa:

Transnational Corporation (TNC) adalah suatu perusahaan yang didirikan di Indonesia menurut hukum Indonesia, tetapi yang secara organisatoris, managerial, finansial, kontraktual ataupun strategis, seluruhnya atau sebagian merupakan bagian daripada satu kesatuan (unit) ekonomi yang lebih besar yang berpusat di salah satu negara di luar negeri. ${ }^{11}$

Menurut Robert Gilpin ada banyak batasan mengenai perusahaan multinasional dengan sejumlah sifat khasnya, yaitu:

"Pertama-tama, perusahaan multinasional melakukan penanaman modal langsung di negara-negara asing dengan pendirian anak atau cabang perusahaan atau pengambilalihan sebuah perusahaan asing. Sasaran penanaman modal tersebut adalah pengawasan manajemen terhadap suatu unit produksi di suatu negara asing. Kedua, perusahaan multinasional ini ditandai dengan adanya perusahaan induk dan sekelompok anak perusahaan atau cabang perusahaan di berbagai negara dengan satu penampungan bersama sumber-sumber manajemen, keuangan dan teknik. Perusahaan induk menjalankan keseluruhannya dalam bentuk suatu strategi dunia yang terkoordinasi. Pembelian, produksi, pemasaran, riset dan lain-lain diatur dan dikelola oleh perusahaan induk dalam usaha mencapai sasaran pertumbuhan perusahaan jangka panjang. Melalui integritas vertikal dan sentralisasi pengambilan keputusan, perusahaan induk berusaha mengekalkan kedudukan monopolinya dalam hal teknologi, modal yang siap pakai dan seterusnya." ${ }^{12}$

Secara global, kehadiran modal asing melalui perusahaantransnasional(TNC)-nya di Indonesia secara efektif bermula pada penghujung tahun

\footnotetext{
Ibid, hlm. 66.

Ibid, hlm. 66.

11 Ibid, hlm. 66.

12 Robert Gilpin dalam T. Mulya Lubis dan Richard M. Buxbaum, Peranan Hukum DalamPerekonomian di Negara Berkembang ( Jakarta: Yayasan Obor Indonesia, 1986), hlm. 17
} 
60-an atau menjelang tahuhn 70-an, dan mencapai puncaknya pada dasawarsa delapan puluhan. Adapun secara umum, prioritas penanaman mereka ternyata lebih terpusatkan pada dua sektor utama. Yakni pengolahan sumber daya alam, terutama pertambangan dan energi, dan industri pengolahan. ${ }^{13}$ Perusahaan tambang seperti PT. Freeport Indonesia dan PT Newmont Indonesia adalah bentuk penanaman modal asing langsung yang datang ke Indonesia selang setelah diundangkannya UU PMA dan UU Pertambangan pada tahun 1967. Berdasarkan ciri perusahaan multinasional yang dikemukakan Robert Gilpin, maka kedua perusahaan yang disebut di atas adalah termasuk kelompok perusahaan multinasional dan merupakan anak perusahaan atau cabang perusahaan di berbagai negara dengan satu penampungan bersama sumber-sumber manajemen, keuangan dan teknik. Sedangkan perusahaan induknya berkedudukan di negara asal investasi, Amerika Serikat. Dari sanalah mereka menjalankan bisnis keseluruhannya dalam bentuk suatu strategi dunia yang terkoordinasi.

\section{Model kerjasama investasi asing sektor pertambangan di Indonesia}

Usaha minerba yang bersifat kontraktual dilakukan dengan menggunakan model kerjasama berupa kontrak karya (Contract of Work), Kontrak Bagi Hasil (Production Sharing Contract), serta Perjanjian Kerjasama Pengusahaan Pertambangan (PKP2B/Coal Contract). Menurut Sunaryati Hartono bahwa Kontrak Karya adalah kontrak antara
Pemerintah Republik Indonesia dengan Perusahaan berbadan hukum Indonesia untuk melaksanakan usaha pertambangan bahan galian, tidak termasuk minyak bumi, gas alam, panas bumi, radio aktif dan batubara. ${ }^{14}$ Sedangkan menurut Nandang Sudrajat bahwa "Kontrak Karya adalah legalitas pengusahaan bahan galian yang diperuntukan bagi investor asing, melalui fasilitas Penanaman Modal Asing (PMA)". ${ }^{15}$ Jadi, kontrak karya merupakan suatu perjanjian antara Pemerintah Indonesia selaku badan hukum privat dengan perusahaan berbadan hukum Indonesia, yang masuk ke Indonesia lewat penanaman modal asing untuk melakukan usaha pertambangan bahan galian.

Kontrak kerjasama antara pemerintah dan badan usaha ini menimbulkan perikatan yang berasal dari perjanjian yang sifatnya khusus, karena menyangkut negara sebagai badan hukum publik di satu pihak dan badan hukum privat di pihak lain. Kontrak karya memberikan kesempatan luas kepada penanaman modal asing untuk berusaha di sektor pertambangan umum. Kontrak karya ini dilakukan oleh pemerintah Indonesia dengan perusahaan berbadan hukum Indonesia, yang merupakan anak perusahaan (subsidiary) dari perusahaan asing, ditandatangani oleh menteri Pertambangan dan perusahaan, serta harus memperoleh persetujuan Presiden dan Dewan Perwakilan Rakyat (DPR). ${ }^{16}$ Negara dan daerah sebagai badan hukum publik sering disebut sebagai sui generis, artinya negara atau daerah sebagai badan hukum publik, tetapi pada saat yang sama sekaligus dapat berperan

Pandji Anoraga, Perusahaan Multinasional ( Jakarta, Pustaka Jaya, cet. 1, 1995), hlm. 86.

Sunaryati Hartono dalam Nanik Trihastuti, Ibid, hal. 92.

Nandang Sudrajat, Teori dan Praktik Pertambangan Indonesia, (Yogyakarta: Pustaka Yustisia, 2013), hlm. 67.

Ibid, hal. 4. 
sebagai badan hukum privat. Dengan demikian, keduanya tidak hanya dapat melaksanakan fungsi publiknya semata, tetapi dapat bertindak sebagai layaknya subjek hukum perdata biasa. ${ }^{17}$ Jadi, kerjasama kontrak karya antara modal asing dengan pemerintah, posisi pemerintah adalah sebagai badan hukum privat.

Berdasarkan skema Kontrak Karya, perusahaan diwajibkan untuk membayar sejumlah pajak mineral, diantaranya royalti ${ }^{18}$ yang nilainya berbeda-beda berdasarkan jenis mineral, sewa tanah dan berbagai jenis pajak berdasarkan tahapan kegiatan Kontrak Karya, seperti pajak perusahaan yang sejak model kontrak karya diperkenalkan berkisar antara 35\%-40\%. Dalam Kontrak Karya, manajemen operasi sepenuhnya berada di tangan Kontraktor, sehingga Kontraktor memiliki hak serta kewenangan mutlak untuk mengatur dan mendahulukan kepentingan perusahaannya dengan mengambil langkah-langkah yang secara pasti akan memberikan keuntungan sebesarbesarnya bagi perusahaan. ${ }^{19}$ Dengan adanya berbagai insentif dan kebijakan pemerintah yang banyak memberikan keuntungan bagi investor, membuat kontrak karya yang merupakan perjanjian yang berbentuk baku ini sangat menarik minat investor untuk menanamkan modalnya di sektor pertambangan umum di Indonesia, dibandingkan modal Kontrak
Bagi Hasil (Production Sharing Contract) sebagaimana yang diterapkan di pertambangan minyak dan gas bumi. ${ }^{20}$

Kontrak karya diatur dalam Pasal 8 ayat (1) UUPMA yang menyebutkan bahwa "Penanaman modal asing di bidang pertambangan didasarkan pada suatu kerja sama dengan Pemerintah atas dasar kontrak karya atau bentuk lain sesuai dengan peraturan perundangan yang berlaku". Bentuk kerjasama yâng dikenal dalam UUPMA No. 1 Tahun 1967 berdasarkan klasifikasi dan/ atau alasan-alasan tertentu, baik politis maupun ekonomis adalah sebagai berikut:

1. Kerja sama dalam bentuk joint venture. Dalam hal ini para pihak tidak membentuk suatu badan hukum yang baru (badan hukum Indonesia);

2. Kerja sama dalam bentuk joint enterprise. Di sini para pihak bersama-sama dengan modalnya (modal asing dan modal nasional) membentuk badan hukum baru yakni badan hukum Indonesia;

3. Kerjasama dalam bentuk kontrak karya, serupa dengan perjanjian kerja sama dalam bidang pertambangan minyak dan gas bumi yang telah ada sebelum UUPMA diundangkan. Dalam bentuk kerja sama tersebut, pihak asing (investor asing) membentuk badan hukum Indonesia

17 Arifin P. Soeria Atmadja, Keuangan Publik dalam Perspektif Hukum: Teori, Kritik dan Praktik (Jakarta: Rajawali Pers, Ed. 1, 2009) hlm. 88.

18 Royalti adalah pajak yang dibayarkan oleh perusahaan untuk hak eksploitasi kekayaan tambang, yang didasarkan pada jumlah tertentu dari jenis bahan galian per ton atau persentase tertentu dari total produksi atau keuntungan. Secara umum terdapat 3 jenis royalti: 1. Royalti kotor (gross royalty) yaitu royalti yang ditentukan berdasarkan volume produksi atau penerimaan kotor (Indonesia menganut jenis royalti ini); 2. Royalty Smelter Return (NSR), yaitu royalti yang dihitung berdasarkan prosentase NSR perusahaan. NSR merupakan gross revenues, dikurangi biaya-biaya pengapalan, peleburan, pemurnian, dan pemasaran; 3. Royalty Net Profit Interest (NPI), dimana royalti dihitung berdasarkan prosentase dari net profit.

19 Ibid, hlm. 5.

$20 \quad$ Ibid, hlm. 5. 
dengan modal asing inilah yang menjadi pihak pada perjanjian yang bersangkutan. ${ }^{21}$

Selanjutnya pengaturan kontrak karya sektor pertambangan secara khusus diatur dalam UU No. 11 Tahun 1967 tentang Pertambangan dalam Pasal 10 bahwa:

(1) Menteri dapat menunjuk pihak lain sebagai kontraktor apabila diperlukan untuk melaksanakan pekerjaan-pekerjaan yang belum atau tidak dapat dilaksanakan sendiri oleh Instansi Pemerintah atau Perusahaan Negara yang bersangkutan selaku pemegang kuasa pertambangan.

(2) Dalam mengadakan perjanjian karya dengan kontraktor seperti yang dimaksud dalam ayat (1) pasal ini Instansi Pemerintah atau Perusahaan Negara harus berpegang pada pedoman-pedoman, petunjuk-petunjuk dan syarat-syarat yang diberikan oleh Menteri.

(3) Perjanjian karya tersebut dalam ayat (2) pasal ini berlaku sesudah disahkan oleh Pemerintah setelah berkonsultasi dengan Dewan Perwakilan Rakyat apabila menyangkut eksploitasi golongan a sepanjang mengenai bahan galian yang ditentukan dalam pasal 13 Undang-undang ini dan/atau yang perjanjian karyanya berbentuk penanaman modal asing.

Dalam perubahan UU Penanaman Modal, model kontrak karya ini tidak lagi diatur. Menurut Aminuddin Ilmar bahwa ketentuan yang mengatur adanya usaha kerja sama patungan sebagaimana ditetapkan dalam Pasal 12 UU Nomor 25 Tahun 2007 tentang Penanaman
Modal mensyaratkan bahwa pelaksanaan atau aplikasi penanaman modal asing di Indonesia dapat dilakukan dalam dua bentuk usaha yaitu: (1) Oleh pihak asing (perseorangan atau badan hukum), kedalam suatu perusahaan yang $100 \%$ diusahakan oleh pihak asing; atau

(2) Dengan menggabungkan modal asing itu dengan modal nasional (swasta nasional). ${ }^{22}$

Secara yuridis hal yang pertama tersebut di atas tidaklah menimbulkan persoalan yang terlalu rumit, oleh karena sudah jelas bahwa bukan hanya modal tetapi kekuasaan maupun pengambilan keputusan (decision making) dilakukan oleh pihak asing, sepanjang segala sesuatu itu memperoleh persetujuan dari pemerintah Indonesia, atau selama pengaturannya tidak melanggar hukum serta ketertiban umum yang berlaku di Indonesia. ${ }^{23}$ Berbeda halnya dengan yang kedua di mana akan lebih sulit oleh karena adanya berbagai variasi kepentingan dalam bentuk usaha kerja sama patungan yang meliputi antara lain: perimbangan modal, kekuasaan (manajemen) yang sesungguhnya, aspek makroekonomis, mikroekonomis, dan aspek sosiokultural. ${ }^{24}$ Untuk kegiatan kerjasama di bidang pertambangan yang padat modal, tentu investor lokal mengalami kesulitan menyediakan modal besar dalam bentuk fresh money guna mengimbangi modal asing.

Berselang dua tahun kemudian setelah berlakunya UU Penanaman Modal, pemerintah menerbitkan UU Minerba yang menentukan bahwa usaha pertambangan modal asing 
hanya diberikan dalam bentuk izin usaha pertambangan khusus (IUPK). Menurut Anthony I. Ogus bahwa apabila dilihat dari kepemilikan objek perizinan, terdapat dua klasifikasi izin publik. Bentuk pertama, pemberian izin dari objek yang bersifat mempunyai kepentingan publik (public interest) sehingga tidak ada hak kepemilikan oleh siapapun karena objek tersebut adalah merupakan public goods dimana harus dapat diakses dan dimanfaatkan oleh siapapun. Bentuk kedua, pemberian izin dari objek yang memang adalah milik publik (public ownership) berarti terkandung makna hak milik seluruh rakyat atau hak milik bangsa, sehingga izin yang diberikan akan berdampak pada kewenangan yang besar dan berbagai hal terkait hak dan kewajiban bagi penerima izin. Oleh karena itu, izin yang dibuat sehubungan dengan kategori public ownership, harus dibuatkan juga dalam suatu perjanjian yang memuat hak dan kewajiban penerima izin, sebagai pengendalian oleh Pemerintah. ${ }^{25}$ Dengan demikian, perizinan usaha pertambangan dalam UU Minerba lebih tepat pada bentuk kedua, dimana izin yang diberikan tersebut merupakan hak milik bangsa Indonesia yang dikuasai negara untuk mengatur dan mengelolanya.

Bentuk perizinan usaha pertambangan yang diatur dalam UU Minerba terdiri dari: Izin Usaha Pertambangan (IUP), Izin Pertambangan Rakyat (IPR), Izin Usaha Pertambangan Khusus (IUPK).

Mengenai IUPK ini diatur mulai dari Pasal 74 sampai dengan Pasal 86 UU Minerba. Kemudian peraturan pelaksanaan UU Minerba tersebut diatur dalam Peraturan Pemerintah Nomor 22 Tahun 2010 tentang Wilayah
Pertambangan, Peraturan Pemerintah Nomor 23 Tahun 2010 tentang Pelaksanaan Kegiatan Usaha Pertambangan Mineral dan Batubara sebagaimana diubah dengan Peraturan Pemerintah Nomor 24 Tahun 2012 dan terakhir diubah dengan Peraturan Pemerintah Nomor 77 Tahun 2014, Peraturan Pemerintah Nomor 55 Tahun 2010 tentang Pembinaan dan Pengawasan Penyelenggaraan Pengelolaan Usaha Pertambangan Mineral dan Batubara, dan Peraturan Pemerintah Nomor 78 Tahun 2010 tentang Reklamasi dan Pasca tambang.

Dari ketiga bentuk perizinan tersebut di atas, tidak secara jelas dapat diketahui bentuk perizinan yang mana sebagai pengganti dari kontrak karya untuk perusahaan tambang modal asing. Apakah IUPK dimaksudkan sebagai pengganti kontrak karya? Kenapa IUPK dikatakan khusus sementara sistem pengelolaan lain, seperti IPR dan IUP tidak dikatakan khusus? Menurut $\mathrm{H}$. Salim HS, kita harus menganalisis dan mengkaji ketentuan-ketentuan yang tercantum dalam UU Minerba dan berbagai peraturan pelaksanaannya. IUPK dikatakan khusus, harus dapat dikaji dari berbagai aspek berikut ini:

1. Pejabat yang berwenang untuk menerbitkan IUPK hanya Menteri Energi dan Sumber Daya Mineral, sementara itu, pejabat yang berwenang menerbitkan IUP, meliputi Menteri Energi dan Sumber Daya Mineral, Gubernur atau Bupati/Walikota.

2. Pemohon yang dapat mengajukan IUPK, meliputi BUMN, BUMD, dan BUS. Sedangkan pemohon IUP terdiri dari badan usaha, koperasi dan perseorangan ${ }^{26}$. Jadi, pemohon IUP dapat perseorangan.

25 Anthony I. Ogus dalam Tri Hayati, P erizinan Pertambangan di Era Reformasi Pemerintahan Daerah: Studi Tentang Perizinan Pertambangan Timah di Pulau Bangka (Jakarta: Badan Penerbit FH UI, 2012), hlm. 27-28.

26 Kholid O santoso(Ed), Mencari demokrasi Gagasan dan Pemikiran, (Bandung, Sega Arsy, 2009) hlm 61 
3. Objek mineral dan logam dan batubara, sedangkan IUP meliputi mineral logam, bukan logam dan batubara.

4. Cara pemberian WIUPK, meliputi prioritas dan lelang.

5. WIUPK nya cukup luas. Untuk IUPK Eksplorasi Mineral dan Logam, seluas 100.000 (seratus ribu) hektare, IUPK Produksi seluas 25.000 hektare. IUPK Eksplorasi Batubara seluas 50.000 (lima puluh ribu) hektare dan IUPK Produksi Batubara seluas 15.000 hektare.

6. Jangka waktunya cukup panjang, yaitu 48 tahun. $^{27}$

Keenam hal di atas, merupakan karakteristik dari IUPK yang tercantum dalam UU Minerba. Menurut H. Salim HS, bahwa IUPK merupakan pengganti sistem pengelolaan pertambangan yang menggunakan sistem kontrak, baik dalam bentuk kontrak karya maupun perjanjian karya pengusahaan pertambangan batubara (PKP2B), sedangkan IUP merupakan pengganti dari kuasa pertambangan (KP). ${ }^{28}$

Dengan demikian kerjasama usaha pertambangan model Kontrak Karya kini telah berakhir, seiring dengan diterbitkannya UU Penanaman Modal dan UU Minerba yang telah menentukan bahwa sebagai pengganti kontrak karya investasi pertambangan modal asing adalah menggunakan IUPK.

Kemudian terhadap renegoisasi kontrak, penerapan UU Minerba terkait renegosiasi kontrak menjadi problema, karena adanya perbedaan prinsip dan kepentingan antara pemerintah dan pihak kontrak karya seperti Freeport. Hal ini bersumber dari ketentuan Pasal 169 UU Minerba yang menyebutkan bahwa Pada saat Undang-Undang ini mulai berlaku:

a. Kontrak karya dan perjanjian karya pengusahaan pertambangan batubara yang telah ada sebelum berlakunya UndangUndang ini tetap diberlakukan sampai jangka waktu berakhirnya kontrak/perjanjian.

b. Ketentuan yang tercantum dalam pasal kontrak karya dan perjanjian karya pengusahaan pertambangan batubara sebagaimana dimaksud pada huruf a disesuaikan selambat-lambatnya 1 (satu) tahun sejak Undang-Undang ini diundangkan kecuali mengenai penerimaan negara.

c. Pengecualian terhadap penerimaan negara sebagaimana dimaksud pada huruf $b$ adalah upaya peningkatan penerimaan negara.

Penjelasan Pasal 169 Huruf b menyebutkan bahwa "Semua pasal yang terkandung dalam kontrak karya dan perjanjian karya pengusahaan pertambangan batubara harus disesuaikan dengan Undang-Undang."

Akibat hukum bagi pemegang kontrak karya dan PKP2B yang tidak mengindahkannya ketentuan Pasal 169 UU Minerba, tidak menyampaikan rencana kegiatan pada seluruh wilayah kontrak sampai dengan berakhirnya kontrak paling lambat 1 (satu) tahun sejak berlakunya kontrak ini, maka berdasarkan Pasal $171^{29}$ UU Minerba, luas wilayah pertambangannya akan disesuaikan dengan 
undang-undang ini. Dalam ketentuan Pasal 83 huruf a UU Minerba menyebutkan bahwa "luas 1 (satu) WIUPK untuk tahap kegiatan eksplorasi pertambangan mineral logam diberikan dengan luas paling banyak 100.000 (seratus ribu) hektare." Dalam siaran pers PT Freeport Indonesia yang diterima Kompas, perusahaan tersebut bersedia mengurangi luas wilayahnya menjadi 90.360 hektar, termasuk penyerahan Blok Wabu kepada pemerintah daerah ${ }^{30}$ dari yang sebelumnya 212.950 hektar. $^{31}$

Dalam renegosiasi amandemen kontrak karya dan PKP2B ini, terdapat enam isu strategis. Keenam isu itu ialah wilayah kerja; kelanjutan operasi pertambangan; penerimaan negara; kewajiban pengolahan dan permurnian dalam negeri; kewajiban divestasi; dan kewajiban penggunaan tenaga kerja lokal serta jasa pertambangan dalam negeri. ${ }^{32}$ Sebagaimana dalam Pasal 169 huruf b di atas, bahwa dalam jangka waktu 1 (satu) tahun sejak UU Minerba diundangkan maka semua pasal dalam kontrak karya dan PKP2B harus menyesuaikan dengan UU Minerba mulai berlaku pada 12 Januari 2009. UU Minerba mulai berlaku pada 12 Januari 2009, sehingga pada 12 Januari 2010 semua pemegang kontrak karya dan PKP2B harus telah menyesuaikan UU Minerba. Namun, pada kenyataannya penyesuaian tersebut tidaklah mudah mengingat bahwa kontrak karya dan PKP2B sebagai perjanjian memiliki krakteristik tertentu. Sebagaimana 2 (dua) perusahaan besar yaitu PT Freeport Indonesia dan PT Newmont Nusa Tenggara meminta Pemerintah Indonesia untuk menghormati klausul-klausul dalam kontrak karya pertambangan. Pemaksaan pemberlakuan UU Minerba merupakan bentuk tumpang tindihnya peraturan di Indonesia, sehingga sangat merugikan investor. ${ }^{33}$ Upaya renegoisasi kontrak karya atau PKP2B mengandung 2 (dua) hal apabila dilihat dari kebijakan renegosiasi tersebut, yaitu: (a) Pemerintah tidak konsisten terhadap pengaturan hitam putih Pasal 169 huruf a tersebut, seharusnya apa yang tertulis secara normatif dilaksanakan sesuai dengan perintah undang-undang; dan (b) masih diakuinya prinsip sanctity of contract, sehingga walaupun undang-undang memerintahkan penyesuaian kontrak karya dan PKP2B dengan UU namun pasal-pasal dalam kontrak mengikat para pihak dan menjadi undang-undang bagi pihak yang membuatnya. ${ }^{34}$ Perumusan Pasal 169 huruf a dengan huruf $b$ sangat kontradiktif dan tidak konsisten. Di satu sisi pemerintah menghargai kontrak karya yang sedang berjalan sebelum terbitnya UU Minerba. Tetapi di sisi lain pemerintah menyuruh perusahaan pemegang kontrak karya paling lambat dalam 1 (satu) tahun menyesuaikan kontrak karya dengan UU Minerba.

kegiatan pada seluruh wilayah kontrak/perjanjian sampai dengan jangka waktu berakhirnya kontrak/ perjanjian untuk mendapatkan persetujuan pemerintah.

(2) Dalam hal ketentuan sebagaimana dimaksud pada ayat (1) tidak terpenuhi, luas wilayah pertambangan yang telah diberikan kepada pemegang kontrak karya dan perjanjian karya pengusahaan pertambangan batubara disesuaikan dengan Undang-Undang ini.

30 Kompas, Sabtu 4 Juli 2015

1 Kompas, Jumat, 3 Juli 2015

32 Prokum,esdm.go.id (diakses 4 Juli 2015 )

33 Ahmad Redi, Hukum Pertambangan, ( Bekasi: Gramata Publishing, 2014) , hlm. 81

$34 \quad$ Ibid, hlm. 87 
Penyesuaian yang dimaksud dalam Pasal 169 huruf $b$ ini yang kemudian menjadi issu yang disebut dengan renegoisasi, dimana isi perjanjian dalam kontrak karya atau PKP2B disesuaikan dengan UU Minerba. Akan tetapi renegoisasi yang dimaksud UU Minerba bukan dalam pengertian hukum perjanjian, yang menempatkan kedudukan kedua-belah pihak seimbang. Sebab, UU Minerba tidak lagi menggunakan model kontrak karya dan PKP2B tetapi menjadi Izin Usaha Pertambangan Khusus (IUPK). Sehingga kedudukan pemerintah dalam konteks ini adalah sebagai badan hukum publik yang memiliki kewenangan-kewenangan di bidang perizinan. Sebagai badan publik ia memiliki kekuasaan untuk memerintah sesuai aturan yang ditentukan dalam UU Minerba. Hukum pertambangan ini adalah aturan yang berisi perintah dan sekaligus mempunyai daya paksa. Apabila tidak dilaksanakan maka akan mendapatkan akibat hukum. Jadi, renegoisasi dalam UU Minerba mengandung unsur paksaan, agar perusahaan pertambangan mengubah isi kesepakatan yang telah dituangkan dalam kontrak. Sekalipun ini bertentangan dengan ketentuan Pasal 1338 KUHPerdata.

Perusahaan tambang PT Freeport dan PT Newmont adalah perusahaan berbadan hukum yang didirikan berdasarkan peraturan perundang-undangan di Indonesia. Oleh karena itu, hukum yang mengatur kontrak karya perusahaan tambang tersebut dengan pemerintah selaku badan hukum privat, adalah didasarkan pada hukum perjanjian yang berlaku saat ini di Indonesia, yaitu KUHPerdata. Dalam Pasal 1320 KUHPerdata disebutkan bahwa "Untuk sahnya suatu persetujuan-persetujuan diperlukan empat syarat: 1 . sepakat mereka yang mengikatkan dirinya; 2 . kecakapan untuk membuat suatu perikatan; 3 . suatu hal tertentu; 4. suatu sebab yang halal." Kemudian dalam Pasal 1338 KUHPerdata disebutkan bahwa: "1. Semua persetujuan yang dibuat secara sah berlaku sebagai undang-undang bagi mereka yang membuatnya; 2. Persetujuan-persetujuan itu tidak dapat ditarik kembali selain dengan sepakat kedua belah pihak, atau karena alasanalasan yang oleh undang-undang dinyatakan cukup untuk itu."

Subekti mengatakan bahwa Pasal 1320 Hukum perjanjian KUHPerdata (BW) ini menganut asas konsensualisme. Artinya ialah: hukum perjanjian dari B.W. ini menganut asas bahwa untuk melahirkan perjanjian, cukup dengan sepakat saja dan bahwa perjanjian itu (dan dengan demikian "perikatan" yang ditimbulkan karenanya) sudah dilahirkan pada saat atau detik tercapainya konsensus sebagaimana dimaksud di atas. Pada detik tersebut perjanjian sudah jadi dan mengikat, bukannya pada detik-detik lain yang terkemudian atau yang sebelumnya. ${ }^{35}$ Pada dasarnya perjanjian dan perikatan yang timbul karenanya itu sudah dilahirkan sejak detik tercapainya kesepakatan. Dengan perkataan lain, perjanjian itu sudah sah apabila sudah sepakat mengenai hal-hal yang pokok dan tidaklah diperlukan sesuatu formalitas. ${ }^{36}$

Berdasarkan hukum perjanjian jelas bahwa kontrak karya dan PKP2B yang telah disepakati tidak mungkin diubah kecuali sepakat kedua belah pihak. Sebab, kontrak karya dan PKP2B tersebut merupakan undang-undang bagi para pihak (Pasal 1338 KUHPerdata). Perlu

Subekti, Aneka Perjanjian, (Jakarta: Alumni, cet. ke-6, 1984) , hlm. 3.

36 Subekti, Hukum Perjanjian, (Jakarta: Intermasa, cet ke-7, 1983) , hlm. 15 
diketahui juga, bahwa kedudukan Pemerintah ketika membuat kesepakatan kontrak karya dan PKP2B tersebut adalah sebagai badan hukum privat. Dalam penyelesaian problema kontrak karya dan PKP2B tidak dapat dipaksakan lewat UU Minerba, karena yang berlaku bagi kedua belah pihak adalah hukum perjanjian. Dengan demikian, pemerintah hanya dapat menunggu hingga berakhirnya kontrak kontrak karya dan PKP2B tersebut, baru lah dapat dilakukan penyesuaian dengan ketentuan UU Minerba.

Dari sudut teori perundang-undangan, perumusan ketentuan Pasal 169 UU Minerba, menunjukan ketidak-konsistenanantara huruf a dan huruf b.Massachusetts General Court dinyatakan dalam Legislative Research and Drafting Manual, prinsip dasar (basic principle) yang harus ada dalam pembentukan undang-undang adalah: $1 . \quad$ Simplicity (kesederhanaan); 2. Conciseness (ringkas dan padat); 3. Consistency (konsisten); Directency (keterusterangan); 4. Appropriate Material for Inclusion (materi yang tepat). ${ }^{37}$ Kemudian Undang-Undang No. 12 Tahun 2011 tentang Pembentukan Peraturan Perundangundangan dalam Pasal 5 disebutkan bahwa "Dalam membentuk Peraturan Perundangundangan harus dilakukan berdasarkan pada asas PembentukanPeraturan Perundangundangan yang baik, antara lain meliputi: a. kejelasan tujuan; b. kejelasan rumusan." Jadi, dalam pembentukan hukumharus konsisten antara pasal dengan pasal dan juga harus ada kejelasan perumusan pasal-pasal nya. Sehingga perundang-undangan tersebut mudah dipahami dan tidak menimbulkan multitafsir serta dapat memberikan kepastian hukum.

Dalam harian Kompas diberitakan bahwa PT Freeport Indonesia sudah mau mengubah Kontrak Karya menjadi izin usaha pertambangan khusus. Menteri Energi dan Sumber Daya Mineral, Sudirman Said mengatakan, kesediaan PT Freeport Indonesia untuk mengubah status operasi mereka sudah disampaikan ke Presiden Joko Widodo. Menurut Presiden, perubahan status tersebut harus dikaji lebih lanjut. ${ }^{38} \mathrm{Hikmahanto}$ berpendapat, pemerintah sebaiknya perlu bertindak hati-hati dalam memutuskan perubahan status operasi Freeport. Kedatangan Chairman Freeport Mc MoRan Inc. James R Moffett yang bertemu dengan Presiden Joko Widodo dapat dinilai sebagai permintaan Freeport terkait percepatan penetapan status IUPK. Pengelolaan tambang di Indonesia, lanjut Hikmahanto, perlu berpijak kepada paradigma kesejahteraan rakyat. ${ }^{39}$

Perubahan komiten PT Freeport Indonesia untuk segera mengubah status Kontrak Karya menjadi IUPK, memang perlu dicermati dengan hati-hati. Jangka waktu kontrak karya Freeport akan berakhir 2021 atau 6 (enam) tahun yang akan datang. Apabila pemerintah menyetujui perubahanstatuskontrakkarya Freeportmenjadi IUPK, maka hitungan matematis berdasarkan UU Minerba Pasal 83 huruf g bahwa "jangka waktu IUPK Operasi Produksi mineral logam atau batubara dapat diberikan paling lama 20 (dua puluh ) tahun dan dapat diperpanjang 2 (dua) kali masing-masing 10 (sepuluh) tahun." Berarti, secara otomatis PT Freeport Indonesia

\footnotetext{
Bayu Dwi Anggono, Perkembangan Pembentukan Undang-Undang di Indonesia, (Jakarta: Konstitusi Press, cet. 1, 2014) , hlm. 53.

38 Kompas, 23 Juni 2015.

$39 \quad$ Kompas, 4 Juli 2015.
} 
mendapatkan perpanjangan operasi produksi tambang, yang seharusnya tinggal 6 (enam) tahun lagi berubah menjadi 20 (dua puluh) tahun ditambah 2 (dua) kali perpanjangan 10 (sepuluh) tahun, sama dengan 40 (empat puluh) tahun lagi Freeport akan menguasai tambang di Timika, Papua. Menurut hemat penulis, pemerintah sebaiknya menunggu jangka waktu kontrak karya Freeport berakhir tahun 2021 dan kembali pada penguasaan Negara. Buat apa mempertahankan kehadiran Freeport kalau tidak memberikan kemanfaatan yang maksimal bagi perekonomian negara guna peningkatan kesejahteraan masyarakat. Sebab, penerimaan negara dari sektor pertambangan ini relatif kecil, sebagaimana telah diuraikan di atas, yang tidak sebanding dengan yang diperoleh perusahaan tambang Freeport. Sebaiknya, pemerintah menyerahkan pengelolaannya pada badan usaha negara seperti PT Aneka Tambang atau badan usaha swasta nasional tentu dengan cara lelang agar memberikan kemanfaatan yang lebih optimal bagi penerimaan negara.

\section{Paradigma hukum investasi pertam- bangan dalam mengoptimalkan pen- dapatan negara}

Dalam Kamus Besar Bahasa Indonesia (KBBI) Paradigma diartikan: 1. daftar semua bentukan dari sebuah kata yg memperlihatkan konjugasi dan deklinasi kata tsb; 2 . model dalam teori ilmu pengetahuan; 3. kerangka berpikir. ${ }^{40}$ Sementara, kebijakan sering dipahami sebagai peraturan perundang-undangan. Menurut PhilipM. Hadjon bahwa peraturan kebijakan, beleidsregel, atau policy rule diciptakan oleh pejabat administrasi negara untuk melaksanakan tugas-tugas pemerintahan. Eksistensi peraturan kebijakan tersebut merupakan konsekuensi atas negara hukum kesejahteraan yang membebankan tugas yang sangat luas, yaitu menyelenggarakan kesejahteraan rakyat (welfare state), kepada pemerintah. ${ }^{41}$ Peraturan kebijakan merupakan produk kebijakan yang bersifat bebas yang ditetapkan oleh pejabat-pejabat administrasi negara dalam rangka penyelenggaraan tugastugas pemerintahan. Kebijakan pejabat administrasi negara tersebut kemudian dituangkan dalam suatu format tertentu supaya dapat diberlakukan secara umum (berlaku sama bagi setiap warga negara). Dalam hal tertentu, bentuk formal peraturan kebijakan sering tidak berbeda atau tidak dapat dibedakan dari format peraturan perundang-undangan. ${ }^{42}$ Namun, proses pembuatan kebijakan publik apa pun pada umumnya berawal dari adanya awareness of a problem (kesadaran akan adanya masalah tertentu). ${ }^{43}$ Pelaksanaan kebijakan pada umumnya diserahkan kepada lembaga-lembaga pemerintahan dalam berbagai jenjangnya hingga jenjang pemerintahan terendah. Di samping itu, setiap pelaksanaan kebijakan masih memerlukan pembentukan kebijakan dalam bentuk peraturan perundang-undangan, atau dalam bentuk peraturan kebijakan 
(beleidsregel). ${ }^{44}$ Pemerintah menyadari kerugian dari penggunaan model kontrak karya pertambangan, sehingga perlu dilakukan perubahan kebijakan investasi pertambangan dengan bentuk perizinan.

Untuk memudahkan memahami apa yang dimaksud dengan kebijakan publik, maka ada baiknya disebutkan ciri-ciri dari suatu kebijakan publik, yaitu:

a. kebijakan adalah suatu tindakan pemerintah yang mempunyai tujuan menciptakan kesejahteraan masyarakat;

b. kebijakan dibuat melalui tahap-tahap yang sistematis sehingga semua variabel pokok dari semua permasalahan yang akan dipecahkan tercakup;

c. kebijakan harus dapat dilaksanakan oleh (unit) organisasi pelaksana, dan;

d. kebijakan perlu dievaluasi sehingga diketahui berhasil tidaknya dalam menyelesaikan masalahan. ${ }^{45}$

Safri Nugraha mengatakan bahwa "Pembentukan kebijakan penanaman modal dan pertambangan ini, merupakan ketentuan yang bertujuan untuk mencapai masyarakat adil dan makmur atau peningkatan kesejahteraan masyarakat sebagaimana diamanatkan Pasal 33 ayat (3) UUD 1945. Namun untuk mencapai tujuan tersebut, disadari berbagai kelemahan terutamaketiadaan modal dan teknologi, sehingga masih dibutuhkan penanaman modal untuk mengolah potensi ekonomi menjadi kekuatan ekonomi riil dengan cara mengundang investor untuk melakukan kegiatan usaha pertambangan mineral dan batubara. Kehadiran investor terutama pemodal asing, diharapkan dapat memberikan nilai tambah secara nyata kepada pertumbuhan ekonomi nasional guna mewujudkan tujuan tersebut.Namun demikian,pengelolaan dan pengendaliannya tetap harus dikuasai Negara sebagai organisasi tertinggi yang memiliki kewenangan-kewenangan dalam bidang perijinan". ${ }^{46}$ Dikuasai oleh negara memaknai hak penguasaan negara atas aset kekayaan alam. Negara berdaulat mutlak atas kekayaan sumber daya alam. Digunakan untuk sebesarbesarnya kemakmuran rakyat dimaknai Hak kepemilikan yang sah atas kekayaan alam adalah rakyat Indonesia. Kedua makna ini merupakan kesatuan. Hak penguasaan negara merupakan instrumen sedangkan "sebesarbesarnya kemakmuran rakyat" adalah tujuan akhir pengelolaan kekayaan alam. ${ }^{47}$

UU PMA menetapkan pradigma investasi di bidang pertambangan didasarkan pada kerjasama dengan Pemerintah atas dasar kontrak karya(Pasal 8 ayat 1). Kemudian dalam UU No. 11 Tahun 1967 tentang Pertambangan, memberikan kewenangan pada Menteri menunjuk pihak lain sebagai kontraktor melakukan pekerjaan-pekerjaan yang belum dapat dilaksanakan oleh Pemerintah atau Perusahaan Negara selaku pemegang kuasa pertambangan. Menyangkut eksploitasi golongan a perjanjiannya karyanya harus berbentuk penanaman modal asing (Pasal 10). Mulai 1981 hingga 1995, penanaman modal

Safri Nugraha dkk, Hukum Administrasi Negara, (Jakarta: Badan Penerbit Fakultas Hukum Universitas Indonesia, 2005), hlm. 207.

45 Ibid, hlm. 205.

46 Lihat Safri Nugraha dkk, Pentingnya perizinan, Ibid, hlm. 136-137.

47 Adrian Sutedi, Hukum Pertambangan, (Jakarta: Sinar Grafika, 2012), hlm. 25. 
asing (PMA) di pertambangan batubara tidak berlaku lagi kontrak karya pertambangan, tetapi Kerjasama Pengembangan Pertambagan Batubara (KKS Batubara), yang kemudian berganti menjadi Perjanjian Kerjasama Pengusahaan Pertambangan (PKB2B). Jika dalam kontrak karya Pertambangan yang menjadi principal adalah pemerintah, maka dalam KKS Batubara dan PKP2B yang menjadi principal adalah perusahaan tambang batubara negara selaku pemegang Kuasa Pertambangan. ${ }^{48}$

Setelah 47 tahun UU PMA dan UU Pertambangan diberlakukan dengan pradigma kebijakan investasiberdasarkankontrakkaryadan PKB2B, ternyata tidak membawa kemanfaatan yang optimal bagi peningkatan kesejahteraan masyarakat. Kuasa tambang yang diperoleh investor asing dalam mengeksploitasi mineral dan batubara, selama ini banyak disalah artikan seolah-olah investor berkuasa atau berdaulat di atas tanah wilayah tambang tersebut. Bahkan pemerintah sebagai regulator tidak dapat mengontrol hasil tambang, yang dieksplorasi perusahaan pertambangan. Akibatnya, tidak mengetahui hasil dari kegiatan pertambangan setelah dimurnikan dan juga tidak mengetahui berapa hasil riilnya keuntungan yang diperoleh investor. Sebab, pemurnian (smelter) dilakukan di negara asal pemodal atau negara lain. Sehingga yang menguasai tambangdi wilayah pertambangan yang ditentukan, sesungguhnya adalah pemegang kontrak karya. Negara hanya mendapatkan pajak dan royalti, yang tidak sebanding dengan yang diperoleh perusahaan tambang.
Ny Hart menyebutkan adanya 6 (enam) konsep dalam ilmu hukum yang mempunyai pengaruh bagi pengembangan kehidupan ekonomi. Salah satu dari keenam konsep tersebut adalah prediktabilitas. Hukum harus mempunyai kemampuan untuk memberikan gambaran pasti di masa depan mengenai keadaan atau hubungan-hubungan yang dilakukan pada masa sekarang. ${ }^{49}$ Berarti UU Penanaman Modal tentang dan UU Minerba harus mempunyai kemampuan memprediksi masa depan yang lebih baik dari pada UU PMA dan UU Pertambangan No. 11 Tahun 1967, dalam memberikan kepastian dan kemanfaatatan bagi kesejahteraan masyarakat. Oleh karena itu, kedua UU baru tersebut tidak lagi mengakomodir model kerjasama kontrak karya tetapi hanya diberikan IUPK bagi modal asing.Namun untuk memberi kepastian hukum atas kontrak karya, maka UU Minerba dalam aturan peralihan menyatakantetap berlaku sampai dengan berakhirnya perjanjian tersebut.Pergeseran pradigma hukum investasi pertambangan ini dimaksudkan untuk mempercepat pembangunan ekonomi nasional guna meningkatkan kesejahteraan masyarakat.

Meskipun masih memerlukan peningkatan modal asing untuk mengolah potensi ekonomi menjadi kekuatan ekonomi riil, tetapi pengelolaan mineral dan batu baramutlak dikuasai oleh Negara dengan menghilangkan unsur kuasa pertambangan pada ketentuan UU Pertambangan dulu. Dengan demikian, UU Minerba dapat memberi nilai tambah secara nyata bagi pertumbuhan perekonomian 
nasional dalam usaha mencapai kemakmuran rakyat secara berkeadilan dan berkepastian. Dengan kepastian yang adil, keadilan yang pasti, dan kebergunaan itulah hukum dapat menjamin kebebasan yang teratur dalam dinamika perekonomian, sehingga pada gilirannya dapat membawa kesejahteraan bersama dalam kehidupan masyarakat. Tanpa kepastian hukum (certainty), perekonomian tidak akan menumbuhkan kebebasan yang sehat dan berkeadilan adil; dan tanpa kebergunaan (utility), perekonomian tidak akan membawa kesejahteraan dan kedamaian. Karena pada akhirnya hukum itu sendiri haruslah membawa kehidupan bersama kepada kesejahteraaan dan kedamaian hidup bersama. ${ }^{50}$

Kemudian dalam UU Minerba, IUPK terdiri atas dua tahap:

a. IUPK Eksplorasi meliputi kegiatan penyelidikan umum, eksplorasi, dan studi kelayakan;

b. IUPK Operasi Produksi meliputi kegiatan konstruksi, penambangan, pengolahan danpemurnian, serta pengangkutan dan penjualan (Pasal 76 (1)).

Dalam IUPK Operasi Produksi harus dimuat antara lain, lokasi pengolahan dan pemurnian,serta divestasi saham (Pasal 79). Mariam Flickinger mendefinisikan divestasi:

“as a firm's decision to dispose of a significant portion of its asets, can increase the strength of a firm by changing its aset structure and its resource allocation patterns." ${ }^{51}$

Dalam definisi ini, divestasi dikonstruksikan sebagai keputusan perusahaan untuk meningkatkan nilai penting dari aset yang dimiliki perusahaan. Tujuannya dapat meningkatkan kekuatan perusahaan dalam mengubah struktur aset dan pengalokasian sumber daya. ${ }^{52}$ Sementara H. Salim HS mendefinisikan divestasi adalah:

"pengalihan aset atau saham yang dimiliki oleh pemerintah dan/atau investor asing kepada pihak lainnya, dan pihak yang terakhir ini berkewajiban untuk memenuhi prestasinya sesuai dengan yang telah ditentukan." ${ }^{\prime 3}$

Pradigma hukum investasi pertambangan juga mencakup perubahan dalam pengelolaan pertambangan mineral dan batubara yang tidak lagi tersentralisasi, tetapi UU Minerba membagi kewenangan antar pemerintah pusat, pemerintah provinsi dan pemerintah kabupaten/kota dalam pemberian Izin Usaha Pertambangan (IUP).

Pandangan mengenai kepastian dan kemanfaatan hukum dalam teori legal utilitarisme yang dipelopori oleh Jeremy Bentham (1748-1832) mengatakan bahwa hukum barulah dapat diakui sebagai hukum, jika ia memberikan kemanfaatan yang sebesar-besarnya terhadap sebanyakbanyaknya orang. ${ }^{54}$ Bagi Jeremy Bentham, tujuan perundang-undangan adalah untuk menghasilkan kebahagiaan bagi masyarakat. Untuk itu perundang-undangan harus berusaha untuk mencapai empat tujuan: a. to provide

\footnotetext{
50 Jimly Asshiddiqie, Konstitusi Ekonomi, ( Jakarta: Kompas Media Nusantara, 2010), hlm. 13.

51 H. Halim HS, Hukum Divestasi di Indonesia: Pasca Putusan Mahkamah Konstitusi RI Nomor 2/SKLN-X/2012,Ed.1, Jakarta: Rajawali Pers, 2013, hlm. 3-4.

Ibid, hlm. 4.

53 Ibid, hlm. 4.

54 Achmad Ali, Menguak Teori Hukum (Legal Theory) \& Teori Peradilan (Judicialprudence): Termasuk Interpretasi Undang-Undang ( Legisprudence) Volume I Pemahaman Awal, (Jakarta: Kencana, 2009), hlm. 76
} 
subsistence (untuk memberi nafkah hidup); b. to provide abundance (untuk memberikan makanan yang berlimpah); c. to provide security (untuk memberikan perlindungan); d. to attain equility (untuk mencapai persamaan). ${ }^{55}$

Sementaraitu, konsep Analisis Ke-Ekonomian Hukum (AKH) oleh Posner mengatakan bahwa Pendekatan dan penggunaan analisis ini harus disusun dengan pertimbangan-pertimbangan ekonomi dengan tidak menghilangkan unsur keadilan, sehingga keadilan dapat menjadi economic standard yang didasari oleh tiga elemen dasar, yaitu nilai (value), kegunaan (utility), dan efisiensi (efficiency) yang didasari oleh rasionalitas manusia. ${ }^{56}$ Berdasarkan konsep dasar ini, AKH yang dikembangkan oleh Posner kemudian dikenal dengan the economic conception of justice, dengan simpulan bahwa hukum diciptakan dan diaplikasikan untuk tujuan utama meningkatkan kepentingan umum seluas-luasnya (maximizing overall social utility). The economic conception of justice menjadi acuan untuk menilai sampai sejauh mana dampak pemberlakuan suatu ketentuan hukum/peraturan perundang-undangan kepada masyarakat luas. ${ }^{57}$

Pemikiran dari Jeremy Bentham dan Posner tersebut di atas, memberikan inspirasi bahwa ketententuan UU Minerba harus dapat memberikan kemanfaatan yang sebesarbesarnya pada masyarakat, yaitu kesejahteraan baik itu pendidikan, lapangan pekerjaan dan sebagainya. Inilah tujuanakhir daridiciptakannya UU Minerba guna memberikan kebahagiaan bagi seluruh masyarakat. Kemanfaatan yang akan diperoleh dari pengaturan UU Minerba bahwa pemerintah dapat mengawasi langsung jumlah tambang yang diproduksi dari hasil pemurnian (smelter) di Indonesia. Sehingga dapat menghitung nilai dari hasil tambang yang telah dimurnikan tersebut bagi peningkatan perekonomian nasional.

Dalam pertimbangan UU Minerba disebutkan bahwa pengelolaan mineral dan batubara harus dikuasai Negara untuk memberi nilai tambah. Hal ini sejalan dengan prinsip dan ajaran mazhab historismus dimana salah satu ajarannya menekankan pentingnya peranan pemerintah dalam perekonomian... Mazhab ini juga menekankan tentang perlunya campur tangan pemerintah dalam perekonomian, karena mereka tidak percaya tentang adanya automatic mechanism (invisible hand) yang mampu memecahkan distorsi pasar sehingga pasar menuju ke suatu keseimbangan (equilibrium) dengan mulus. ${ }^{58}$ Frederich List dipandang sebagai pelopor pemikiran ekonomi pada mazhab historismus. Menurut List, sistem liberalisme yang laissez-faire tidak dapat menjamin alokasi sumberdaya secara optimal. Perkembangan ekonomi-menurut Listtergantung pada peran pemerintah, dunia bisnis, dan lingkungan kebudayaan. List menegaskan bahwa negara harus melindungi kepentingan golongan lemah dalam masyarakat. ${ }^{59}$

Campur tangan pemerintah dalam meningkatkan perekonomian pada umumnya telah diterima secara luas. Hal ini bermula dari 
teori Adam Smith, yang mengatakan bahwa apabila perseorangan dibiarkan memenuhi kepentingannya sendiri, maka suatu invisible hand akan menjaga bahwa kepentingan umum dengan sendirinya akan terselenggara. ${ }^{60}$ Setelah tahun 1930 (dengan terjadinya melaise dan pengangguran) teori Adam Smith itu meleset sama sekali, mulailah orang memikirkan konsep baru, yang kemudian dikenal dengan pemikiran negara kesejahteraan (welvaarstaat). Menurut teori ini, maka tidak boleh tidak negara (dan pemerintah sebagai alat negara) perlu ikut campur tangan dalam kehidupan perekonomian, agar supaya dapat dicegah keadaan yang oleh Karl Marx diuraikan dalam Verelendungs-theorienya, karena l'exploitation de l'homme par l'homme. ${ }^{61}$

Dengan pengelolaan yang dilakukan pemerintah merupakan bentuk campur tangan, yang diharapkan dapat memberikan nilai tambah optimal dalam pertumbuhan ekonomi.Menurut Lincolin Arsyad bahwanilai tambah adalah bagian dari pendapatan nasional merupakan nilai keseluruhan barang dan jasa yang dihasilkan oleh suatu perekonomian (negara) dalam satu periode tertentu. Perhitungan pendapatan nasional dapat dilakukan dengan tiga metode, yaitu metode produksi (nilai tambah), metode pendapatan, dan metode pengeluaran. ${ }^{62}$ Menurut metode produksi (nilai tambah), pendapatan nasional dihitung dengan cara menjumlahkan nilai tambah (value added) yang diciptakan oleh sektor-sektor produktif. Cara ini dilakukan untuk menghindari terjadinya perhitungan berganda (double counting). Oleh karena itu, metode produksi juga dikenal dengan istilah metode nilai tambah (value added). Di Indonesia, sektor-sektor produktifnya terbagi ke dalam 9 sektor, yaitu: pertanian, peternakan, kehutanan dan perikanan, pertambangan dan penggalian; industri pengolahan; listrik, gas dan air minum; bangunan; perdagangan, hotel dan jasa-jasa. Jumlah nilai akhir produksi barang dan jasa yang dihasilkan oleh sektor-sektor tersebut dalam satu tahun fiskal disebut dengan Gross Domestic Product (GDP) atau Gross National Product (GNP) yang dalam bahasa Indonesianya disebut sebagai Produk Domestik Bruto (PDB) atau Produk Nasional Bruto (PNB). ${ }^{63}$ Penerimaan negara yang diperoleh dari kegiatan pertambangan dalam setiap tahunnya akan menjadi bagian pendapatan nasional. Jika kegiatan pertambangan tersebut memberikan nilai tambah yang maksimum, maka akan terjadi perubahan tingkat pendapatan nasional dari tahun ke tahun. Dengan memperbandingkan pendapatan nasional dari tahun ke tahun inilah dapat diketahui telah terjadi pertumbuhan ekonomi. Dari 9 sektor yang dikemukakan diatas, akan terlihat sektor mana yang memberikan nilai tambah yang signifikan bagi pertumbuhan ekonomi.

\section{Penutup}

Penyesuaian kontrak karya dan PKP2B dengan UU Minerba sebagaimana diperintahkan ketentuan Pasal 169 huruf b, yang dikenal dengan renegoisasi bertentangan dengan hukum perjanjian. Berdasarkan hukum perjanjian bahwa kontrak karya dan PKP2B yang

\footnotetext{
Sunaryati Hartono, Hukum Ekonomi Pembangunan Indonesia, (Jakarta: BPHN - Binacipta, 1982), hlm. 46.

61 Ibid, hlm. 46

62 Lincolin Arsyad,Op.cit., hlm. 20.

63 Ibid, hlm. 20.
} 
telah disepakati tidak mungkin diubah kecuali sepakat kedua belah pihak, karena kontrak karya dan PKP2B merupakan undang-undang bagi para pihak (Pasal 1320 dan 1338 KUHPerdata). Sebab pada saat kontrak disepakati, kedudukann pemerintah ketika itu adalah bertindak sebagai badan hukum privat yang berkedudukan sama dengan badan hukum privat perusahaan pertambangan. Keinginan PT Freeport yang akhirnya mau mengubah kontrak karya pertambangannya, harus disikapi dengan hatihati. Perlu diingat bahwa Kontrak PT Freeport akan berakhir 2021 atau lebih kurang 6 (enam) tahun lagi. Apabila pemerintah memberikan izin IUPK berarti PT Freeport akan mendapatkan IUPK Operasi Produksi dengan jangka waktu 20 (dua puluh) tahun dan dapat diperpanjang 2 (dua) kali masing-masing 10 (sepuluh) tahun sesuai ketentuan Pasal 83 huruf g UU Minerba. Sehingga Freeport akan mengelola usaha pertambangan freeport berdasarkan IUPK sebanyak 40 (empat puluh) tahun lagi. Oleh karena itu, sebaiknya Pemerintah menunggu berakhirnya kontrak karya Freeport tahun 2021 sesuai yang ditentukan dalam Pasal 169 huruf a, agar memberikan kepastian hukum pada usaha pertambangan. Dengan berakhirnya kontrak karya tersebut, pemerintah kelak dapat membuka lelang baru bagi pengelolaan tambang Timika yang menguntungkan bagi Indonesia.

Pergeseran pradigma hukum investasi pertambangan di Indonesia dari Kontrak Karya menjadi IUPK, menjadikan Negara berkuasa atas mineral dan tambang. Pergeseran pradigma ini diharapkan akan dapat memberikan nilai tambah (value added) yang diciptakan oleh sektor-sektor produktif seperti pertambangan bagi peningkatan pendapatan pada perekonomian nasional. Sehingga akan memberikan kemanfaatan yang sebesarbesarnya pada masyarakat, yaitu kesejahteraan baik itu pendidikan, lapangan pekerjaan dan sebagainya. Inilah tujuan akhir dari diciptakannya UU Minerba guna memberikan kebahagiaan bagi seluruh masyarakat. Kemanfaatan lain yang akan diperoleh dari pengaturan UU Minerba bahwa pemerintah dapat mengawasi langsung jumlah tambang yang diproduksi dari hasil pemurnian (smelter) di Indonesia. Dengan demikian dapat diketahui apa saja hasil akhir dari pengerukan tambang tersebut, untuk menghindari kerugian negara. Pergeseran pradigma ini memberikan kepastian hukum bahwa tambang harus dikuasai Negara untuk menentukan dan mengatur hubungan hukum antara pemerintah dan perusahaan tambang, sehingga dapat memberikan nilai tambah bagi perekonomian nasional.

\section{DAFTAR PUSTAKA}

\section{Buku}

Abdul Wahab, Solichin, Analisis Kebijaksanaan; dari formulasi ke implementasi kebijaksanaan negara -Ed.2, Cet.2 - ( Jakarta: Bumi Aksara, 2001)

Ali, Achmad, Menguak Teori Hukum (Legal Theory) \& Teori Peradilan (Judicialprudence): Termasuk Interpretasi Undang-Undang (Legisprudence) Volume I Pemahaman Awal, (Jakarta: Kencana, 2009)

Amrizal, Hukum Bisnis: Deregulasi dan Joint Venture di Indonesia, Teori dan Praktik, (Jakarta: Djambatan, 1996)

Anoraga, Pandji, Perusahaan Multinasional, cet. 1, (Jakarta, Pustaka Jaya, 1995)

Arsyad, Lincolin, Ekonomi Pembangunan, (Yogyakarta: STIM YKPN, cet. 1, 2010)

Asshiddiqie, Jimly, Konstitusi Ekonomi, ( Jakarta: Kompas Media Nusantara, 2010)

Atmadja, Arifin P. Soeria, Keuangan Publik dalam Perspektif Hukum: Teori, Kritik dan Praktik, Ed. 1, (Jakarta: Rajawali Pers, 2009) 
Dwi Anggono, Bayu, Perkembangan Pembentukan Undang-Undang di Indonesia, cet. 1, (Jakarta: Konstitusi Press, 2014)

Hartono, Sunaryati, Hukum Ekonomi Pembangunan Indonesia, (Jakarta: BPHN - Binacipta, 1982)

Hayati, Tri, Perizinan Pertambangan di Era Reformasi Pemerintahan Daerah: Studi Tentang Perizinan Pertambangan Timah di Pulau Bangka, (Jakarta: Badan Penerbit FH UI, 2012)

HS, H. Salim, Hukum Divestasi di Indonesia: Pasca Putusan Mahkamah Konstitusi RI Nomor 2/ SKLN-X/2012,- Ed.1, (Jakarta: Rajawali Pers, 2013)

HS, H. Salim, Hukum Pertambangan di Indonesia, Ed.1- Cet. 6 - (Jakarta: Rajawali Pers, 2012)

HS, H. Salim, Hukum Pertambangan Mineral dan Batubara, Ed.1. Cet.2, (Jakarta: Sinar Grafika, 2014)

Ilmar, Aminuddin, Hukum Penanaman Modal di Indonesia, (Jakarta: Kencana, 2010)

Lubis, T. Mulya dan Richard M. Buxbaum, Peranan Hukum Dalam Perekonomian di Negara Berkembang, (Jakarta: Yayasan Obor Indonesia, 1986)

M. Hadjon, Philip dalam Dr. Hotma P. Sibuea, S.H., M.H., Asas Negara Hukum: Peraturan Kebijakan, Asas-asas Umum Pemerintahan yang Baik, (Jakarta: Erlangga, 2010)

Marzuki, Peter Mahmud, Penelitian Hukum, (Jakarta: Kencana, 2011)

Nugraha dkk, Safri, Hukum Administrasi Negara, (Jakarta: Badan Penerbit Fakultas Hukum Universitas Indonesia, 2005)

Redi, Ahmad, Hukum Pertambangan, (Bekasi: Gramata Publishing, 2014)

Rokhmatussadyah, Ana dan Suratman, Hukum Investasi \& Pasar Modal, (Ed.1, Cet.2, Jakarta: Sinar Grafika, 2011)

Soekanto, Soerjono dan Sri Mamuji, Penelitian Hukum Normatif: Suatu Tinjauan Singkat, (Jakarta: Raja Grafindo Persada, 2001)

Subekti, Aneka Perjanjian,( Jakarta: Alumni, cet. ke6, 1984)
Subekti, Hukum Perjanjian, (Jakarta: Intermasa, cet ke-7, 1983)

Sudrajat, Nandang, Teori dan Praktik Pertambangan Indonesia, (Yogyakarta: Pustaka Yustisia, 2013)

Sugianto, Fajar, Economic Analysis of Law: Seri Analisis Ke-ekonomian tentang Hukum Seri I Pengantar, (Jakarta: Kencana, 2013)

Sutedi, Adrian ,Hukum Pertambangan,(Jakarta: Sinar Grafika, 2012)

Trihastuti, Nanik, Hukum Kontrak Karya: Pola Kerjasama Pengusahaan Pertambangan Indonesia, ( Malang: Setara Perss, kelompok Penerbit Intrans, 2013)

\section{Makalah/Artikel/Prosiding/Hasil Penelitian}

Sulistiyono, Adi, Orasi Ilmiah Pengangkatan Guru Besar di Universitas Sebelas Maret,

(Surakarta 17 Nopember 2000)

\section{Internet}

http://www.hukumonline.com (diakses 19 Juni 2015)

http.//www.hukumonline.com (diakses 19 Juni 2015)

http://kbbi.web.id/paradigma (diakses 30 Juni 2015)

\section{Peraturan}

Undang-Undang Nomor 12 Tahun 2011 tentang Pembentukan Peraturan Perundang-undangan

Undang-Undang Nomor 4 Tahun 2009 tentang Pertambangan Mineral dan Batubara

Undang-Undang Nomor 40 Tahun 2007 tentang Perseroan Terbatas

Undang-Undang Nomor 25 Tahun 2007 tentang Penanaman Modal

Undang-Undang Nomor 11 Tahun 1967 tentang Pokok-Pokok Pertambangan

Undang-Undang Nomor 1 Tahun 1967 tentang Penanaman Modal Asing 